Article

\title{
Nitrous Oxide Adsorption and Decomposition on Zeolites and Zeolite-like Materials
}

\author{
Leonid M. Kustov 1,2,3,*, Sergey F. Dunaev ${ }^{1,2,3}$ and Alexander L. Kustov 1,2,3 \\ 1 Chemistry Department, Moscow State University, 1 Leninskie Gory, Bldg. 3, 119991 Moscow, Russia; \\ dunaev@general.chem.msu.ru (S.F.D.); kyst@list.ru (A.L.K.) \\ 2 N.D. Zelinsky Institute of Organic Chemistry RAS, 47 Leninsky Prosp., 119991 Moscow, Russia \\ 3 Institute of Ecotechnologies and Engineering, National University of Science and Technology MISiS, \\ 4 Leninsky Prosp., 119049 Moscow, Russia \\ * Correspondence: lmkustov@mail.ru orlmk@ioc.ac.ru
}

Citation: Kustov, L.M.; Dunaev, S.F.; Kustov, A.L. Nitrous Oxide Adsorption and Decomposition on Zeolites and Zeolite-like Materials. Molecules 2022, 27, 398. https:// doi.org/10.3390/molecules27020398

Academic Editor: Giuseppe Cirillo

Received: 18 December 2021

Accepted: 6 January 2022

Published: 8 January 2022

Publisher's Note: MDPI stays neutral with regard to jurisdictional claims in published maps and institutional affiliations.

Copyright: (C) 2022 by the authors. Licensee MDPI, Basel, Switzerland. This article is an open access article distributed under the terms and conditions of the Creative Commons Attribution (CC BY) license (https:// creativecommons.org/licenses/by/ $4.0 /)$.

\begin{abstract}
Decomposition of $\mathrm{N}_{2} \mathrm{O}$ on modified zeolites, crystalline titanosilicalites, and related amorphous systems is studied by the catalytic and spectroscopic methods. Zinc-containing HZSM-5 zeolites and titanosilicalites with moderate $\mathrm{Ti} / \mathrm{Si}$ ratios are shown to exhibit a better catalytic performance in $\mathrm{N}_{2} \mathrm{O}$ decomposition as compared with conventionally used $\mathrm{Cu} / \mathrm{HZSM}-5$ zeolites and amorphous $\mathrm{Cu}$-containing catalysts. Dehydroxylation of the HZSM-5 zeolite by calcination at $1120 \mathrm{~K}$ results in an enhancement of the $\mathrm{N}_{2} \mathrm{O}$ conversion. The mechanism of the reaction and the role of coordinatively unsaturated cations and Lewis acid sites in $\mathrm{N}_{2} \mathrm{O}$ decomposition are discussed on the basis of the spectroscopic data.
\end{abstract}

Keywords: HZSM-5 zeolite; $\mathrm{N}_{2} \mathrm{O}$ decomposition; titanosilicalites; Lewis acid sites; diffuse-reflectance IR spectroscopy

\section{Introduction}

The problem of $\mathrm{N}_{2} \mathrm{O}$ decomposition remains to gradually attract attention in view of the development of green technologies. This problem is related to the synthesis of adipic acid, which yields $\mathrm{N}_{2} \mathrm{O}$ as a side product, as well as $\mathrm{NO}_{x}$ abatement in exhaust gases of power plants or waste anesthetic gas purification. Furthermore, the reaction of $\mathrm{N}_{2} \mathrm{O}$ decomposition was shown to be the initial and key stage in the processes of selective oxidation of aromatic compounds with $\mathrm{N}_{2} \mathrm{O}$ under mild conditions using zeolites as catalysts [1-6]. It was shown that coordinatively unsaturated cations (iron species and framework Lewis acid sites) are responsible for the catalytic activity of dehydroxylated HZSM- 5 zeolites both in $\mathrm{N}_{2} \mathrm{O}$ decomposition and in the reactions of oxidation of various aromatic substrates using $\mathrm{N}_{2} \mathrm{O}$ [3-5]. In the art, oxide systems are known as $\mathrm{N}_{2} \mathrm{O}$ decomposition catalysts, with amorphous copper oxide, for instance, $\mathrm{Cu}-\mathrm{Me} / \mathrm{Al}_{2} \mathrm{O}_{3}$, as well as cobalt oxide systems [7], magnesium cobaltite $\mathrm{Mg}_{x} \mathrm{Co}_{1-x} \mathrm{Co}_{2} \mathrm{O}_{4}$ [8], $\mathrm{CoO}_{x}-\mathrm{CeO}_{2}$ [9] or Co-Ce spinel [10] as quite active, although most of the Co-based catalysts, except for the Co-Ce spinel, demonstrate high conversion only at high temperatures (870-1070 K). Ceria-zirconia behaves nearly similar to Co-oxide materials [11].

Other supported catalysts, such as rhodium on lanthanum silicate $\mathrm{Rh} / \mathrm{La}_{10} \mathrm{Si}_{6-x} \mathrm{Fe}_{x} \mathrm{O}_{27-\delta}$ or $\mathrm{Pt} / \mathrm{ZrO}_{2}$ providing a $100 \% \mathrm{~N}_{2} \mathrm{O}$ conversion at temperatures as high as $870 \mathrm{~K}[12,13]$ or $\mathrm{Pt}$, Ir, and Pd supported on $\mathrm{Al}_{2} \mathrm{O}_{3}$ [14] have been also studied. However, the use of noble metals seems to be an expensive way to $\mathrm{N}_{2} \mathrm{O}$ abatement. Furthermore, carbon nanotubes were predicted by DFT calculations to catalyze this reaction [15].

Among the most efficient catalysts used for $\mathrm{N}_{2} \mathrm{O}$ decomposition, high-silica zeolites modified with iron [5,16], rhodium [17], copper [18], ruthenium [19], and mixed Co-In [20] ions were shown to demonstrate the best performance. The reported catalysts provide a complete conversion of nitrous oxide to nitrogen and oxygen at $620 \mathrm{~K}$. $\mathrm{Ru}(0)$ nanoclusters 
prepared by the reduction of $\mathrm{Ru}(\mathrm{III})$ ions, as well as osmium(III) species were found to be less active compared with ruthenium ions. The systems containing $\mathrm{Fe}, \mathrm{Cu}, \mathrm{Co}$, and $\mathrm{Ru}$ metal ions exhibited a much better catalytic performance in $\mathrm{N}_{2} \mathrm{O}$ decomposition as compared with other modified and non-modified zeolites [21], as well as other amorphous oxide systems [22,23]. The main disadvantages revealed, for example, by the Cu-catalysts for $\mathrm{N}_{2} \mathrm{O}$ decomposition are their low thermal stability (they irreversibly lose the activity after overheating to $\mathrm{T}>870 \mathrm{~K}$ ) and poor tolerance to admixtures of $\mathrm{H}_{2} \mathrm{O}, \mathrm{CO}, \mathrm{CO}_{2}$, and hydrocarbons, which are present in real gas mixtures and act as poisons. The behavior of catalysts definitely depends on the presence of water vapor in the feed, as well as other residual components $\left(\mathrm{NO}, \mathrm{O}_{2}, \mathrm{NO}_{2}\right)$ that may interfere with the $\mathrm{N}_{2} \mathrm{O}$ decomposition process [24]. However, in the mixture, we will limit our scope with the model conditions, without the introduction of other potentially important ingredients.

The aim of this work was to find new zeolite and zeolite-like catalysts that are active in $\mathrm{N}_{2} \mathrm{O}$ decomposition and to study the nature of active sites and plausible reaction mechanisms, with an emphasis on the role of coordinatively unsaturated cations. Three groups of catalysts were chosen for the investigation:

- Dehydroxylated HZSM-5 zeolites and ZSM-5 zeolites modified with zinc oxide, which have been studied earlier from the point of view of the nature and strength of Lewis acid sites $[25,26]$, i.e., the systems containing strong coordinatively unsaturated cations (Lewis acid sites);

- Crystalline Ti-silicalites that are widely used as efficient catalysts for the selective oxidation of phenol into diphenols by $\mathrm{H}_{2} \mathrm{O}_{2}$ in the liquid phase [27];

- Amorphous catalysts, based on the $\mathrm{Ti} / \mathrm{SiO}_{2}$ system, which differ in the $\mathrm{Ti} / \mathrm{Si}$ ratio and in the preparation method.

For comparative purposes, the well-known Cu-ZSM-5-type catalysts for $\mathrm{N}_{2} \mathrm{O}$ decomposition, as well as amorphous $\mathrm{Cu}$-containing oxide systems were also studied.

\section{Results and Discussion}

To evaluate the relative strength of coordinatively unsaturated cations in the modified zeolites under study and to rank the samples according to the relative concentration of strong electron-acceptor centers, IR spectra of molecular hydrogen, as a probe for lowcoordinated cations [28], were measured.

Figure 1 shows the IR spectra of $\mathrm{H}_{2}$ adsorbed at $77 \mathrm{~K}$ on three representative samples containing rather strong coordinatively unsaturated cations: (1) Dehydroxylated HZSM-5 zeolite, (2) Cu/HZSM-5, and (3) Zn/HZSM-5. The absorption bands in the region of $4100-4120 \mathrm{~cm}^{-1}$ correspond to weakly bonded $\mathrm{H}_{2}$ complexes with bridging $\mathrm{Si}(\mathrm{OH}) \mathrm{Al}$ and terminal $\mathrm{SiOH}$ groups, respectively [28], whereas the bands below $4100 \mathrm{~cm}^{-1}$ are shown [28] to belong to complexes of molecular hydrogen with coordinatively unsaturated cations (or Lewis acid sites) that exhibit electron-accepting properties. The stronger the interaction in the complex, i.e., the stronger the electron-acceptor center, the larger the shift of the corresponding band of adsorbed $\mathrm{H}_{2}$ toward lower frequencies measured relative to the frequency of the $\mathrm{H}-\mathrm{H}$ stretching vibration in the gas phase $\left(\nu_{\mathrm{H}^{-} \mathrm{H}}=4163 \mathrm{~cm}^{-1}\right)$ [28]. As seen from the spectra shown in Figure 1, the strongest coordinatively unsaturated cations are present in the $\mathrm{Zn} / \mathrm{ZSM}-5$ zeolite $\left(v_{\mathrm{H}-\mathrm{H}}=3955,4010\right.$ and $4070 \mathrm{~cm}^{-1}$, for these bands $\Delta v_{\mathrm{H}^{-} \mathrm{H}}=208,153$, and $93 \mathrm{~cm}^{-1}$, respectively), whereas the weakest centers among the three catalysts under consideration are revealed in the dehydroxylated HZSM-5 zeolite $\left(\nu_{\mathrm{H}^{-} \mathrm{H}}\right.$ $=4010$ and $4035 \mathrm{~cm}^{-1}, \Delta v_{\mathrm{H}^{-} \mathrm{H}}=153$ and $128 \mathrm{~cm}^{-1}$, respectively). The $\mathrm{Cu} / \mathrm{ZSM}-5$ zeolite, which is the well-known active catalyst for $\mathrm{N}_{2} \mathrm{O}$ decomposition, manifests an intermediate strength of the electron-acceptor centers $\left(\nu_{\mathrm{H}^{-} \mathrm{H}}=3970\right.$ and $4060 \mathrm{~cm}^{-1}, \Delta v_{\mathrm{H}^{-} \mathrm{H}}=193$ and $103 \mathrm{~cm}^{-1}$, respectively). Of note, the concentration of the strongest electron-acceptor centers is the highest for the $\mathrm{Zn} / \mathrm{HZSM}-5$ zeolite. Moreover, it is noteworthy that a further increase in the loading of copper in the Cu/HZSM- 5 zeolite from 1 to $3 \mathrm{wt} \%$, as well as an increase in the loading of zinc in the $\mathrm{Zn} / \mathrm{HZSM}-5$ zeolite over $5 \mathrm{wt} \%$, have no appreciable effect on the 
spectral pattern, i.e., the concentration of strong Lewis acid sites. Furthermore, this increase does not improve the catalytic performance of the $\mathrm{Cu}$-zeolite and $\mathrm{Zn}$-zeolite catalysts.

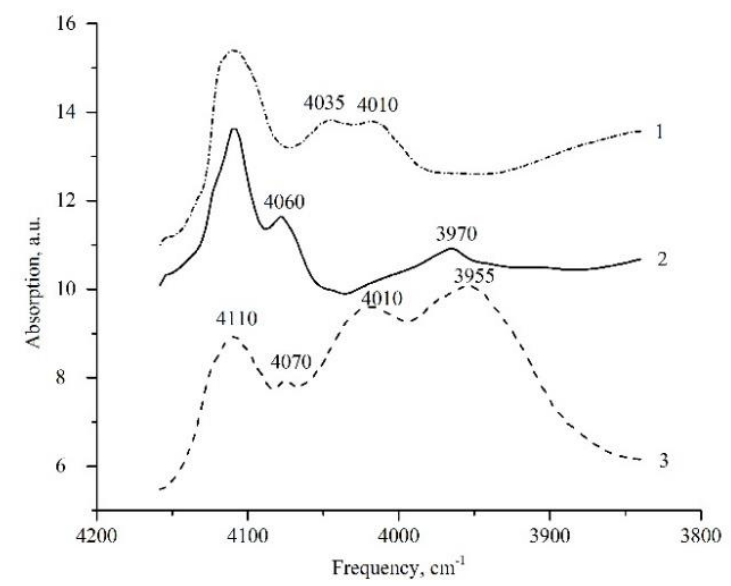

Figure 1. IR spectra of $\mathrm{H}_{2}$ adsorbed at $77 \mathrm{~K}$ on: (1) Dehydroxylated HZSM-5 zeolite; (2) Cu/HZSM-5; (3) Zn/HZSM-5.

The pre-adsorption of a small amount of $\mathrm{N}_{2} \mathrm{O}$ at $300 \mathrm{~K}$ on the zeolite samples, which precedes the adsorption of $\mathrm{H}_{2}$ results in the disappearance of the low-frequency absorption bands attributed to the $\mathrm{H}_{2}$ complexes with low-coordinated cations. However, this has no considerable influence on the intensity of the high-frequency bands $\left(v_{\mathrm{H}^{-} \mathrm{H}}=4100-4120 \mathrm{~cm}^{-1}\right)$ assigned to the complexes with $\mathrm{OH}$ groups. This experiment shows that adsorption of $\mathrm{N}_{2} \mathrm{O}$ occurs on the low-coordinated metal cations that are responsible for the appearance of the corresponding absorption bands in the IR spectra of adsorbed hydrogen.

The adsorption of $\mathrm{N}_{2} \mathrm{O}$ on the zeolite samples results in the appearance of the absorption bands at $2285-2230 \mathrm{~cm}^{-1}$ (Figure 2). The frequency of gaseous $\mathrm{N}_{2} \mathrm{O}$ is $2224 \mathrm{~cm}^{-1}$. Herein, we observe one band at $2230 \mathrm{~cm}^{-1}$, which is close to the gas-phase value (physically adsorbed $\mathrm{N}_{2} \mathrm{O}$ ) and a shifted band at $2285 \mathrm{~cm}^{-1}$ due to complexes with zinc species (electron-acceptor centers). The largest shift of the $\mathrm{N}_{2} \mathrm{O}$ band with respect to the corresponding band position for $\mathrm{N}_{2} \mathrm{O}$ molecules in the gas phase is observed for $\mathrm{Zn} / \mathrm{HZSM}-5$ zeolites $\left(v=2285 \mathrm{~cm}^{-1}, \Delta v=50 \mathrm{~cm}^{-1}\right)$, which indicates the strongest polarization and activation of the $\mathrm{N}_{2} \mathrm{O}$ molecule by the electron-acceptor sites of the $\mathrm{Zn} / \mathrm{HZSM}-5$ zeolite. According to our previous spectroscopic data and quantum-chemical calculation [1,2], the $\mathrm{N}_{2} \mathrm{O}$ molecule is preferably adsorbed on the Lewis acid center (for instance, on trigonally coordinated aluminum ions) by a two-point mechanism, which also involves a neighboring oxygen atom of the surface cluster. In this case, adsorption of $\mathrm{N}_{2} \mathrm{O}$ is accompanied by a considerable change of the geometry of the molecule, in particular, by a substantial decrease of the NNO angle (from 180 to $140^{\circ}$ ) and by a strong polarization of the $\mathrm{N}-\mathrm{O}$ bond, which favors the further decomposition of the $\mathrm{N}_{2} \mathrm{O}$ molecule with the evolution of $\mathrm{N}_{2}$ into the gas phase and chemisorption of atomic oxygen [1,2]. Evidently, the extent of $\mathrm{N}_{2} \mathrm{O}$ polarization and activation, and thus, the rate of decomposition are governed by the strength of coordinatively unsaturated cations. Correspondingly, heating of the Zn/HZSM-5 zeolite with pre-adsorbed $\mathrm{N}_{2} \mathrm{O}$ at $520 \mathrm{~K}$ for $1 \mathrm{~h}$ directly in the IR cell (under static conditions) leads to the complete decomposition of $\mathrm{N}_{2} \mathrm{O}$, and the bands at $2285-2240 \mathrm{~cm}^{-1}$ vanish from the spectrum, whereas the corresponding band at $2355 \mathrm{~cm}^{-1}$ appears due to the molecular nitrogen formed upon the $\mathrm{N}_{2} \mathrm{O}$ decomposition. For comparison, heating of the dehydroxylated HZSM-5 zeolite with pre-adsorbed $\mathrm{N}_{2} \mathrm{O}$ at $520 \mathrm{~K}$ for $1 \mathrm{~h}$ results only in a partial decomposition of $\mathrm{N}_{2} \mathrm{O}$, in accordance with a weaker strength of the low-coordinated cations (Lewis acid sites). 


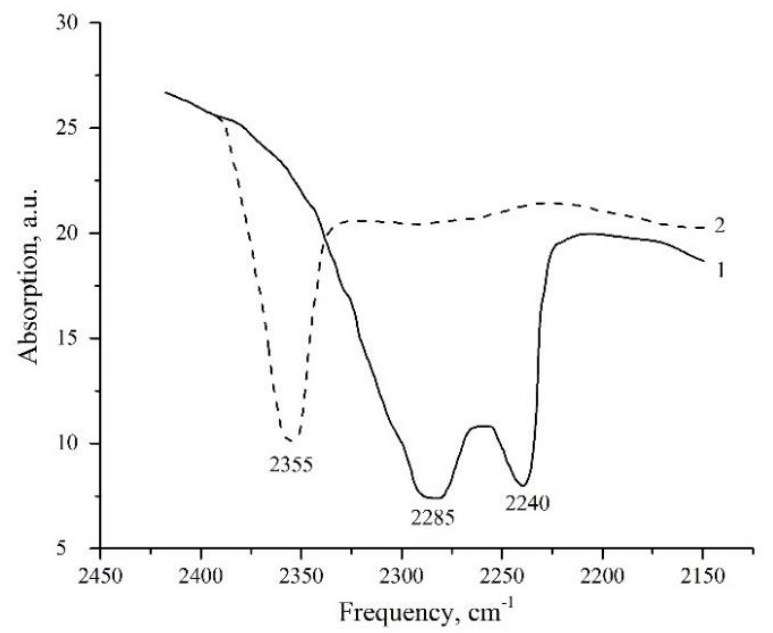

Figure 2. (1) IR spectra of $\mathrm{N}_{2} \mathrm{O}$ adsorbed at $300 \mathrm{~K}$ on $\mathrm{Zn} / \mathrm{HZSM}-5$; (2) IR spectra upon heating the $\mathrm{Zn} / \mathrm{HZSM}-5$ zeolite at $520 \mathrm{~K}$ for $1 \mathrm{~h}$ with pre-adsorbed $\mathrm{N}_{2} \mathrm{O}(300 \mathrm{~K})$.

To reveal subtle distinctions in the properties of the modified zeolites related to $\mathrm{N}_{2} \mathrm{O}$ decomposition, we tested the samples in the flow catalytic unit at $620-900 \mathrm{~K}$. The reaction conditions and the conversion degrees for the $\mathrm{N}_{2} \mathrm{O}$ decomposition on the modified HZSM-5 zeolites and some $\mathrm{Cu}$-containing amorphous catalysts used for $\mathrm{NO}_{x}$ decomposition are summarized in Table 1. In agreement with the spectroscopic data, the dehydroxylated HZSM-5 zeolite exhibits a poor conversion even at enhanced temperatures (720 K), and the $\mathrm{Zn}$-containing zeolites reveal the best performance. These catalysts are active at low temperatures as $620 \mathrm{~K}$ (the conversion of $85 \%$ ), while the known Cu/HZSM- 5 system exhibits a considerable inferior performance (the conversion does not exceed $20 \%$ ) under the same conditions. Of note, both samples of the amorphous $\mathrm{Cu}$-containing catalysts show a poor performance as compared with the $\mathrm{Zn}$ - and $\mathrm{Cu}$-zeolites. The presence of low-coordinated metal ions (zinc or copper) should clearly be considered as the prerequisite for the efficient $\mathrm{N}_{2} \mathrm{O}$ decomposition. Therefore, the spectroscopic and catalytic data indicate that strong electron-acceptor (low-coordinated) metal ions, which should actually be considered as Lewis acid-base pair sites containing a low-coordinated metal ion and an oxygen anion of the framework, are presumably the active centers responsible for the $\mathrm{N}_{2} \mathrm{O}$ decomposition on the modified zeolites. With the analogy from our previous studies and taking into account the results of quantum-chemical calculations [1,2], we may propose the following mechanism of $\mathrm{N}_{2} \mathrm{O}$ decomposition on strong coordinatively unsaturated metal ions, which involves strong perturbation of the $\mathrm{N}_{2} \mathrm{O}$ molecule and further formation of the chemisorbed oxygen atom. Here, the latter is consumed for the recombination or scavenged by the second $\mathrm{N}_{2} \mathrm{O}$ molecule, yielding $\mathrm{N}_{2}$ and $\mathrm{O}_{2}$ (Scheme 1):

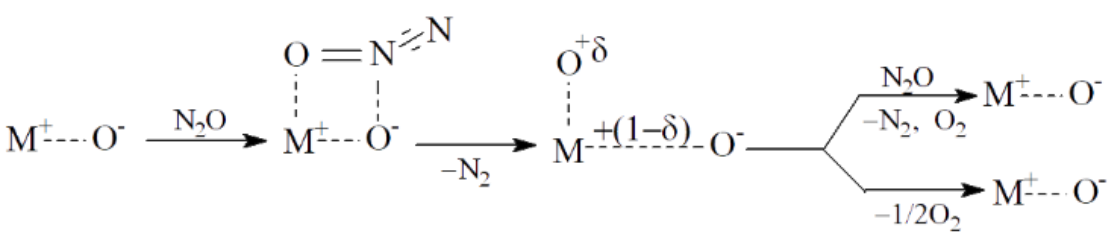

Scheme 1. Mechanism of $\mathrm{N}_{2} \mathrm{O}$ decomposition on Lewis acid-base pair sites. 
Table 1. $\mathrm{N}_{2} \mathrm{O}$ decomposition ( $45 \mathrm{~cm}^{3} \mathrm{~N}_{2} \mathrm{O} / \mathrm{min}$ ).

\begin{tabular}{|c|c|c|c|}
\hline Catalyst & $\begin{array}{c}\text { Reaction } \\
\text { Temperature, } \mathrm{K}\end{array}$ & $\mathrm{N}_{2} \mathrm{O}$ Conversion, $\%$ & $\begin{array}{c}\text { TOF, } \\
\text { mmol } \mathrm{N}_{2} \mathrm{Og}^{-1} \mathrm{~s}^{-1}\end{array}$ \\
\hline $\begin{array}{l}\text { Conventionally calcined } \\
\text { HZSM-5 (770 K) }\end{array}$ & 720 & 12 & 0.020 \\
\hline $\begin{array}{l}\text { Dehydroxylated } \\
\text { HZSM-5 (970 K) }\end{array}$ & 720 & 55 & 0.046 \\
\hline $3 \% \mathrm{Zn} / \mathrm{HZSM}-5$ & $\begin{array}{l}620 \\
645 \\
660\end{array}$ & $\begin{array}{c}85 \\
90 \\
100\end{array}$ & $\begin{array}{l}0.071 \\
0.075 \\
0.084\end{array}$ \\
\hline $5 \%$ Zn/HZSM-5 & $\begin{array}{l}620 \\
645\end{array}$ & $\begin{array}{c}85 \\
100\end{array}$ & $\begin{array}{l}0.071 \\
0.084\end{array}$ \\
\hline $3 \% \mathrm{Cu} / \mathrm{HZSM}-5$ & $\begin{array}{l}620 \\
645 \\
660 \\
670 \\
\end{array}$ & $\begin{array}{c}20 \\
55 \\
85 \\
100\end{array}$ & $\begin{array}{l}0.017 \\
0.046 \\
0.071 \\
0.084\end{array}$ \\
\hline $\mathrm{Co} / \mathrm{Cr} / \mathrm{Cu} / \mathrm{Al}_{2} \mathrm{O}_{3}$ & $\begin{array}{l}645 \\
670\end{array}$ & $\begin{array}{l}45 \\
80\end{array}$ & $\begin{array}{l}0.038 \\
0.067\end{array}$ \\
\hline
\end{tabular}

The second group of catalysts studied in the reaction of $\mathrm{N}_{2} \mathrm{O}$ decomposition comprised crystalline Ti-silicalites with different $\mathrm{Si} / \mathrm{Ti}$ ratios and amorphous $\mathrm{TiO}_{2}-\mathrm{SiO}_{2}$ systems. The Ti-silicalites have been chosen for the investigation in the title reaction, since they exhibit unique catalytic properties in the reactions of selective oxidation of phenol into diphenols using $\mathrm{H}_{2} \mathrm{O}_{2}$ as an oxidizing agent $[27,29]$. The active centers responsible for these properties of the Ti-silicalites are should be titanyl groups $\mathrm{Ti}=\mathrm{O}$ or isolated tetrahedral $\mathrm{Ti}^{+4}$ ions [29]. Accordingly, the reaction is assumed to involve Ti-OOH fragments in the coordination sphere of the isolated $\mathrm{Ti}^{+4}$ ions. Taking into account the fact that the $\mathrm{N}_{2} \mathrm{O}$ molecule contains labile oxygen, similar to the $\mathrm{H}_{2} \mathrm{O}_{2}$ molecule, and with due regard to the similarity of the reaction mechanisms for the selective oxidation with $\mathrm{N}_{2} \mathrm{O}$ and $\mathrm{H}_{2} \mathrm{O}_{2}$, which include activation and decomposition of the molecule of the oxidizing agent, we may assume that the catalysts which are active in the reactions involving $\mathrm{H}_{2} \mathrm{O}_{2}$, i.e., Ti-silicalites, will be active in the reaction of $\mathrm{N}_{2} \mathrm{O}$ decomposition.

Table 2 presents the results of catalytic testing of various Ti systems in the reaction of $\mathrm{N}_{2} \mathrm{O}$ decomposition. The $\mathrm{N}_{2} \mathrm{O}$ conversion for the crystalline Ti-silicalites of the TS- 1 type (four samples) passes through a maximum at $\mathrm{Si} / \mathrm{Ti}=32$. Of note, the performance of the crystalline Ti-silicalite with the $\mathrm{Si} / \mathrm{Ti}$ ratio equal to 32 is higher than the known $\mathrm{Cu} / \mathrm{HZSM}$ 5 catalyst, especially at low temperatures (620-645 K). The dome-shaped dependence of the $\mathrm{N}_{2} \mathrm{O}$ decomposition rate for the Ti-silicalites versus the $\mathrm{Si} / \mathrm{Ti}$ ratio may be accounted for in the following way. Evidently, a decrease in the performance with the increasing $\mathrm{Si} / \mathrm{Ti}$ ratio from 32 to 38 results from a diminution of the concentration of active isolated $\mathrm{Ti}^{+4}$ ions in the framework. A decrease in the conversion degree when the Ti content in the samples increases (the $\mathrm{Si} / \mathrm{Ti}$ ratio decreases to 20-15), may be equally explained by a decrease in the concentration of the active isolated $\mathrm{Ti}^{+4}$ species as a result of the growth of the concentration of the pair $\mathrm{Ti}^{+4}$ centers, which are likely inactive (or less active, as compared with the isolated $\mathrm{Ti}^{+4}$ species). The concentration of the isolated $\mathrm{Ti}^{+4}$ species may also decrease due to the formation of octahedral $\mathrm{Ti}^{+4}$ centers, in particular, extraframework octahedral species, for instance, in the form of anatase, which is inactive in the $\mathrm{N}_{2} \mathrm{O}$ decomposition, at least in the temperature range studied. The latter hypothesis is consistent with the data presented by Bellussi et al. [30], who showed that the probability of the formation of anatase (or in general, octahedral $\mathrm{Ti}^{+4}$ ions) during the synthesis of Ti-silicalites of the TS- 1 type drastically increases, when the Si/Ti ratio approaches 20 and lower values. 
Table 2. Results of catalytic testing of various Ti-systems in the reaction of $\mathrm{N}_{2} \mathrm{O}$ decomposition.

\begin{tabular}{|c|c|c|c|c|c|}
\hline Catalyst & $\mathrm{Si} / \mathrm{Ti}$ & $\mathrm{T}, \mathrm{K}$ & $\begin{array}{c}\mathrm{N}_{2} \mathrm{O} \text { Flow } \\
\text { Rate, } \mathrm{cm}^{3} / \mathrm{min}\end{array}$ & $\begin{array}{c}\text { Conversion } \\
\text { of } \mathrm{N}_{2} \mathrm{O}, \%\end{array}$ & $\begin{array}{c}\text { TOF, } \\
\mathrm{mmol} \mathrm{N}_{2} \mathrm{Og}^{-1} \mathrm{~s}^{-1}\end{array}$ \\
\hline \multirow[t]{2}{*}{ TS-1 (I) } & 14.4 & 770 & 20 & 15 & 0.006 \\
\hline & & 870 & & 20 & 0.008 \\
\hline \multirow[t]{2}{*}{ TS-1 (II) } & 22.9 & 770 & 20 & 10 & 0.004 \\
\hline & & 870 & & 50 & 0.019 \\
\hline \multirow[t]{3}{*}{ TS-1 (III) } & 32.0 & 620 & 45 & 55 & 0.046 \\
\hline & & 645 & & 80 & 0.067 \\
\hline & & 670 & & 85 & 0.071 \\
\hline \multirow[t]{3}{*}{ TS-1 (IV) } & 37.9 & 620 & 45 & 45 & 0.038 \\
\hline & & 645 & & 60 & 0.050 \\
\hline & & 670 & & 80 & 0.067 \\
\hline \multirow[t]{2}{*}{$\mathrm{TiO}_{2}-\mathrm{SiO}_{2}$} & 17.0 & 720 & 45 & 10 & 0.008 \\
\hline & & 820 & & 50 & 0.042 \\
\hline
\end{tabular}

For a comparison with the crystalline Ti-silicalites, we also tested the performance of amorphous $\mathrm{TiO}_{2}-\mathrm{SiO}_{2}$ samples. Here, it is known [31] that the amorphous $\mathrm{Ti} / \mathrm{SiO}_{2}$ is completely inactive in the reaction of selective oxidation of phenol with aqueous solutions of $\mathrm{H}_{2} \mathrm{O}_{2}$. Moreover, these samples exhibited a very low conversion in the reaction of $\mathrm{N}_{2} \mathrm{O}$ decomposition. Furthermore, they revealed some $\mathrm{N}_{2} \mathrm{O}$ conversion only at high temperatures of $720-770 \mathrm{~K}$, while the crystalline Ti-silicalites with a close $\mathrm{Si} / \mathrm{Ti}$ ratio were very active at $620 \mathrm{~K}$.

To ascertain the coordination state of titanium ions in the crystalline and amorphous Ti-systems, we used the XPS method. Figure 3 depicts the representative XP spectra of two crystalline samples and one amorphous catalyst. The spectra contain a characteristic line of $\mathrm{Ti}_{3} \mathrm{p}_{3} / 2$ in the range of the binding energies of $460.0-458.7 \mathrm{eV}$. For the Ti-silicalite with a moderate $\mathrm{Si} / \mathrm{Ti}$ ratio (32), a sharp peak at $460.0 \mathrm{eV}$ is observed, which is ascribed to tetrahedrally coordinated $\mathrm{Ti}^{+4}$ ions, whereas for Ti-silicalites with lower Si/Ti ratios (22.9 and 14.4), a superposition of the peak at $460.0 \mathrm{eV}$ with the second line with the maximum at $458.7 \mathrm{eV}$ is revealed as a result of the presence of octahedrally coordinated $\mathrm{Ti}^{+4}$ ions. A similar spectral pattern is observed for the amorphous $\mathrm{TiO}_{2}-\mathrm{SiO}_{2}$ sample.

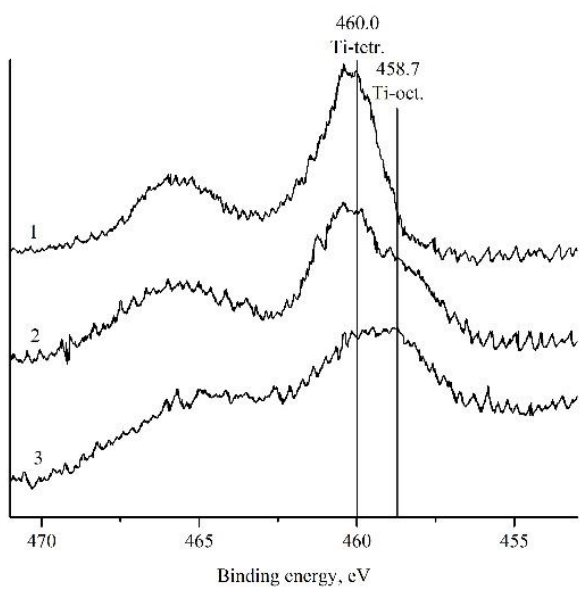

Figure 3. Representative XP spectra: (1) TS-1(I) (Si/Ti = 14.4); (2) TS-1 (II) ( $\mathrm{Si} / \mathrm{Ti}=22.9)$; (3) TS-1(III) $(\mathrm{Si} / \mathrm{Ti}=32)$. 
With an analogy regarding the chemistry of processes based on $\mathrm{H}_{2} \mathrm{O}_{2}$, one may consider two plausible reaction mechanisms for $\mathrm{N}_{2} \mathrm{O}$ decomposition on the Ti-silicalites (Scheme 2):

1)
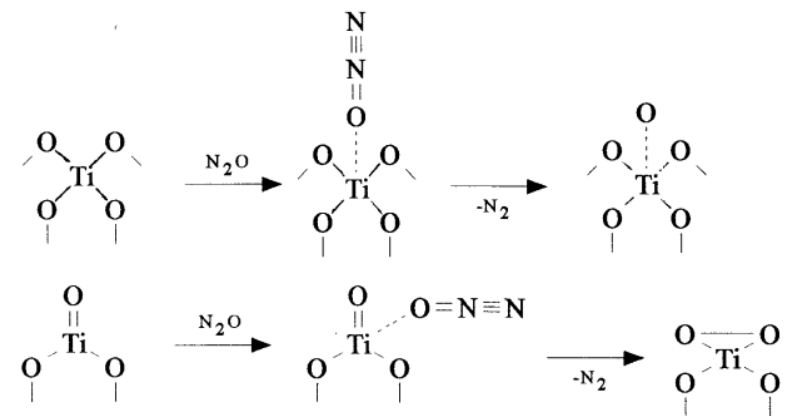

Scheme 2. Mechanism of $\mathrm{N}_{2} \mathrm{O}$ decomposition on Ti-centers.

The first mechanism is similar to the one proposed for the modified zeolites containing coordinatively unsaturated cations, such as Zn/HZSM-5, except for the fact that $\mathrm{Ti}^{+4}$ ions are not in the trigonal but in the tetragonal coordination. However, taking into account the fact that (1) for $\mathrm{Ti}^{+4}$ ions the characteristic coordination numbers are 4 and 6 , and (2) tetragonal $\mathrm{Ti}^{+4}$ ions in the framework of Ti-silicalites are capable of coordinating additional adsorbate molecules, we may consider the first mechanism as one of the possible ways of $\mathrm{N}_{2} \mathrm{O}$ transformation. The aforementioned XPS data lend some support for this mechanism of $\mathrm{N}_{2} \mathrm{O}$ decomposition. However, of note, the presence of five-coordinated titanium ions cannot be excluded, since the XPS pattern represents a superposition of at least two, maybe three lines. The five-coordinated titanium ions are also coordinatively unsaturated and therefore, can take part in the reaction. The second mechanism involves a cyclic peroxo complex, which also seems quite probable in view of the data obtained for the so-called "reactive silica" [32]. In any case, discrimination between these two mechanisms should be done in the future research, probably, with the help of labelled isotopes of oxygen.

Figure 4 displays the IR spectra of two samples of the crystalline Ti-silicalites measured after $\mathrm{N}_{2} \mathrm{O}$ adsorption at room temperature and after heating the sample with pre-adsorbed $\mathrm{N}_{2} \mathrm{O}$ at $520 \mathrm{~K}$ directly in the IR cell under static conditions. Unlike Zn/HZSM- 5 zeolites, the adsorption of $\mathrm{N}_{2} \mathrm{O}$ does not result in a considerable polarization and perturbation of the molecule, and the band position for adsorbed $\mathrm{N}_{2} \mathrm{O}\left(\Delta v_{\mathrm{H}^{-} \mathrm{H}}=2235-2225 \mathrm{~cm}^{-1}\right)$ is very close to the physically adsorbed $\mathrm{N}_{2} \mathrm{O}$. Nevertheless, heating of the samples at $570 \mathrm{~K}$ for $1 \mathrm{~h}$ results in the complete (the sample with $\mathrm{Si} / \mathrm{A}=32$ ) or considerable (the sample with $\mathrm{Si} / \mathrm{Al}=14.4$ ) disappearance of the $\mathrm{N}_{2} \mathrm{O}$ absorption bands. Simultaneously, the bands of $\mathrm{N}_{2}$ at 2360-2340 $\mathrm{cm}^{-1}$ are formed, thereby indicating the decomposition of $\mathrm{N}_{2} \mathrm{O}$. These data agree fairly well with the catalytic data presented in Table 2. 


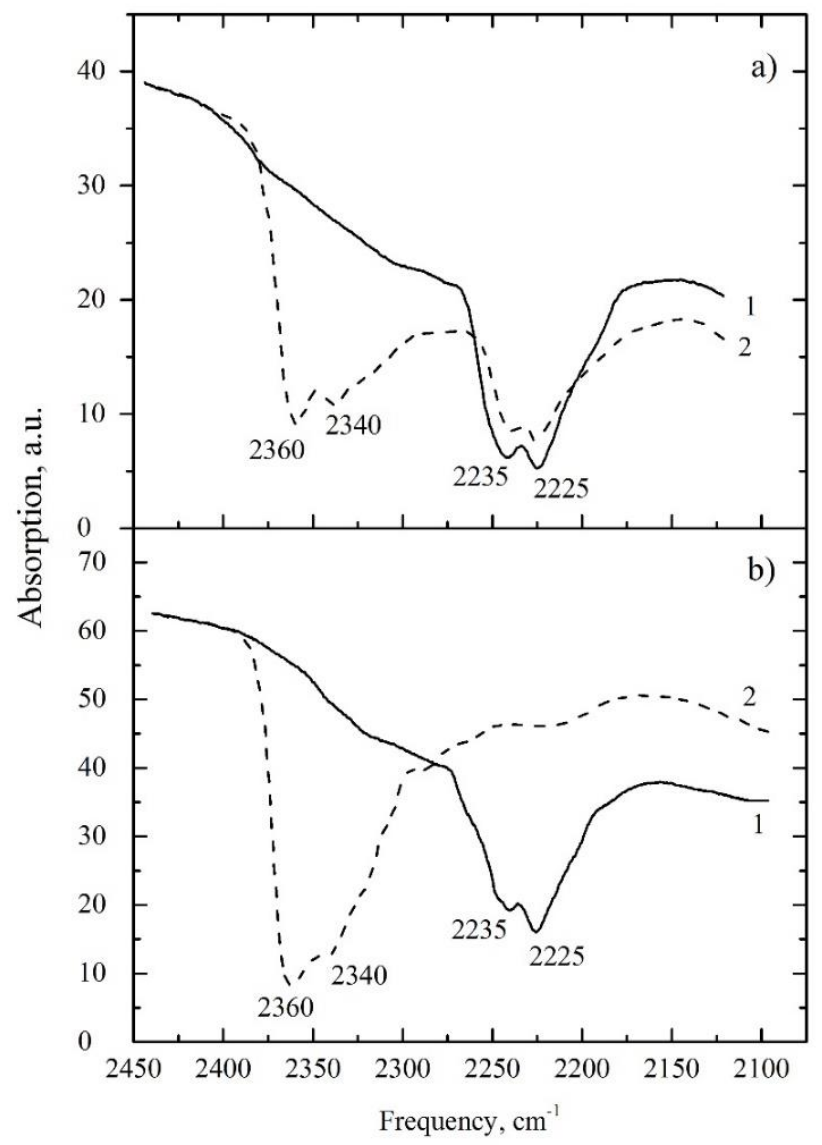

Figure 4. IR spectra of $\mathrm{N}_{2} \mathrm{O}$ adsorbed on TS-1 ( $\left.\mathrm{Si} / \mathrm{Ti}=14.4\right)(\mathbf{a})$ and $\mathrm{TS}-1(\mathrm{Si} / \mathrm{Ti}=32)(\mathbf{b})$ at $300 \mathrm{~K}(1)$ and upon heating the samples at $570 \mathrm{~K}$ for $1 \mathrm{~h}$ with pre-adsorbed $\mathrm{N}_{2} \mathrm{O}(300 \mathrm{~K})$ (2).

\section{Materials and Methods}

The dehydroxylated HZSM- 5 zeolite was prepared by calcination of the HZSM-5 zeolite $(\mathrm{Si} / \mathrm{Al}=20)$ in a vacuum at $1120 \mathrm{~K}$ for $2 \mathrm{~h}$. Zn/HZSM- 5 catalysts with $\mathrm{ZnO}$ loadings of $1-5 \mathrm{wt} \%$ were synthesized by wet impregnation of the HZSM- 5 zeolite with a $1 \mathrm{M}$ aqueous solution of $\mathrm{Zn}\left(\mathrm{NO}_{3}\right)_{2}$, with further drying at $390 \mathrm{~K}$ in air and successive calcination in air at $820 \mathrm{~K}$ for $4 \mathrm{~h}$ and $920 \mathrm{~K}$ for $4 \mathrm{~h}$. Four samples of crystalline Ti-silicalites of the TS-1 type with $\mathrm{Si} / \mathrm{Ti}$ ratios of $14.4,22.9,32.0$, and 37.9 were prepared according to the known procedure [30]. The $\mathrm{Cu} / \mathrm{HZSM}-5$ zeolite with $3 \mathrm{wt} \% \mathrm{Cu}$, which corresponded to the maximum conversion on the zeolite in $\mathrm{N}_{2} \mathrm{O}$ decomposition, was prepared by wet impregnation of the HZSM- 5 zeolite similar to the Zn/HZSM-5 samples. The crystallinity of the zeolites and Ti-silicalites under study, monitored by XRD, was close to $95-100 \%$.

Samples of amorphous $\mathrm{Ti} / \mathrm{SiO}_{2}$ catalysts were prepared by the method of chemical vapor deposition (CVD) using $\mathrm{TiCl}_{4}$ and the sample of silica gel with successive hydrolysis or by coprecipitation of $\mathrm{TiO}_{2}$ and $\mathrm{SiO}_{2}$. The resulting $\mathrm{Ti} / \mathrm{SiO}_{2}$ catalysts were characterized by $\mathrm{TiO}_{2}$ loadings of $0.5-80 \mathrm{wt} \%$. The $\mathrm{Co}-\mathrm{Cr}-\mathrm{Cu} / \mathrm{Al}_{2} \mathrm{O}_{3}$ catalyst for $\mathrm{N}_{2} \mathrm{O}$ decomposition was prepared by the co-precipitation of equimolar amounts of $\mathrm{Co}, \mathrm{Cr}$, and $\mathrm{Cu}$ from their nitrate precursors, in the presence of $\gamma-\mathrm{Al}_{2} \mathrm{O}_{3}$ (surface area, $170 \mathrm{~m}^{2} / \mathrm{g}$ ) with further calcination at $770 \mathrm{~K}$ for $2 \mathrm{~h}$.

In this paper, the structure of all the studied zeolite samples, including the starting HZSM-5, dehydroxylated HZSM-5, Zn/HZSM-5, Cu/HZSM-5, and TS-1 samples with any $\mathrm{Si} /$ Ti ratio, present the same MFI type, as determined by XRD.

Prior to the catalytic tests, all of the samples were activated at $770 \mathrm{~K}$ for $4 \mathrm{~h}$ in an air flow. The catalytic reaction of $\mathrm{N}_{2} \mathrm{O}$ decomposition was studied in a flow setup at $620-900 \mathrm{~K}$ and an $\mathrm{N}_{2} \mathrm{O}+\mathrm{He}$ (1:1) flow rate of $20-60 \mathrm{~mL} / \mathrm{min}$. The sample loading was $0.2 \mathrm{~g}$. The catalyst $(0.5-1 \mathrm{~mm}$ particle size) was diluted with quartz (1:1). The reaction products and 
unreacted $\mathrm{N}_{2} \mathrm{O}$ were analyzed by gas chromatography (a Krystalux chromatograph) using a 1-m Porapak $\mathrm{Q}$ column. The only products of $\mathrm{N}_{2} \mathrm{O}$ decomposition were $\mathrm{N}_{2}$ and $\mathrm{O}_{2}$. Diffusereflectance IR spectra were measured in the range of $4000-8000$ and $2000-4000 \mathrm{~cm}^{-1}$ with a Beckman Acta-M-VII; and Perkin-Elmer 580 B spectrophotometer, respectively, according to the reported procedures [28]. Molecular hydrogen adsorbed at $77 \mathrm{~K}$ and a pressure of 30 Torr were used as a probe for coordinatively unsaturated cations [28,29]. Nitrous oxide was adsorbed on the samples at $300 \mathrm{~K}$ and a pressure of 10-30 Torr.

XP spectra were measured with a XSAM-800 spectrometer using the MgKa excitation. The $\mathrm{C}_{1 \mathrm{~S}}$ line at $285.0 \mathrm{eV}$ was used as a reference.

\section{Conclusions}

In conclusion, the obtained catalytic and spectroscopic data allow the arrangement of the systems under study in the following sequence, and according to their performance in $\mathrm{N}_{2} \mathrm{O}$ decomposition: Zn/HZSM-5 > TS-1 (III) > Cu/HZSM-5 > TS-1 (IV) > (Co, $\mathrm{Fe}) / \mathrm{Cr} / \mathrm{Cu} / \mathrm{Al}_{2} \mathrm{O}_{3}>\mathrm{HZSM}-5>\mathrm{TS}-1$ (I), TS-1 (II), $\mathrm{TiO}_{2}-\mathrm{SiO}_{2}$. In addition, from these data, two new catalytic compositions, i.e., ZnO/HZSM-5 and Ti-silicalite, with a moderate Si/Ti ratio, exhibit a better performance in the reaction of $\mathrm{N}_{2} \mathrm{O}$ decomposition, as compared with the conventional $\mathrm{Cu}$-containing zeolite and oxide catalysts. The key role played by coordinatively unsaturated $\mathrm{Zn}, \mathrm{Cu}$ or Ti ions, as non-framework $(\mathrm{Zn}, \mathrm{Cu})$ or framework ions in the $\mathrm{N}_{2} \mathrm{O}$ decomposition has been revealed. Even the dehydroxylated HZSM-5 zeolite, containing rather strong Lewis acid sites (but still weaker than those in Zn/HZSM-5 catalysts), is more active in the reaction of $\mathrm{N}_{2} \mathrm{O}$ decomposition compared with the conventionally calcined HZSM-5 zeolite, which contains predominantly Bronsted acid sites. Furthermore, a considerably high $\mathrm{N}_{2} \mathrm{O}$ conversion reaching $85 \%$ is observed for the most active catalysts $(\mathrm{Zn} / \mathrm{HZSM}-5)$ under rather mild reaction conditions $(\mathrm{T}=620 \mathrm{~K})$.

Author Contributions: Conceptualization, L.M.K. and S.F.D.; methodology, A.L.K.; investigation, A.L.K.; writing—original draft preparation, L.M.K.; writing-review and editing, L.M.K. All authors have read and agreed to the published version of the manuscript.

Funding: This work was supported by the Institute of Organic Chemistry of the Russian Academy of Sciences (Program of supporting scientific schools).

Institutional Review Board Statement: Not applicable.

Informed Consent Statement: Not applicable.

Data Availability Statement: Not applicable.

Conflicts of Interest: The authors declare no conflict of interest.

Sample Availability: Samples of the modified ZSM-5 zeolites and titanosilicates are available from the authors.

\section{References}

1. Zholobenko, V.L.; Senchenya, I.N.; Kustov, L.M.; Kazansky, V.B. Complexation and decomposition of $\mathrm{N}_{2} \mathrm{O}$ on Broensted acid sites in high-silicon zeolites. Spectral and quantum chemical study. Kinet. Catal. 1991, 32, 151-157.

2. Zholobenko, V.L.; Kustov, L.M.; Kazansky, V.B. The role of Lewis acid sites in adsorption and activation of oxygen in redox type reactions on zeolites. In Proceedings of the of the 9th International Zeolite Conference, Boston, MA, USA, 5-10 July 1992; Volume 2, pp. 299-302.

3. Ono, Y.; Tohmori, K.; Suzuki, S.; Nakashiro, K.; Suzuki, E. Functionalization of benzene by its reaction with nitrogen oxides over solid-acid catalysts. Stud. Surf. Sci. Catal. 1998, 41, 75-82.

4. Uriarte, A.K.; Rodkin, M.A.; Gross, M.J.; Kharitonov, A.S.; Panov, G.I. Direct hydroxylation of benzene to phenol by nitrous oxide. Stud. Surf. Sci. Catal. 1997, 110, 857-864.

5. Panov, G.I.; Sobolev, V.L.; Kharitonov, A.S. The role of iron in $\mathrm{N}_{2} \mathrm{O}$ decomposition on ZSM-5 zeolite and reactivity of the surface oxygen formed. J. Molec. Catal. 1990, 61, 85-97. [CrossRef]

6. Sun, K.; Xia, H.; Feng, Z.; van Santen, R.; Hensen, E.; Li, C. Active sites in Fe/ZSM-5 for nitrous oxide decomposition and benzene hydroxylation with nitrous oxide. J. Catal. 2008, 254, 383-396. [CrossRef] 
7. Wilczkowska, E.; Krawczyk, K.; Petryk, J.; Sobczak, J.W.; Kaszkur, Z. Direct nitrous oxide decomposition with a cobalt oxide catalyst. Appl. Catal. A General 2010, 389, 165-172. [CrossRef]

8. Abu-Zied, B.M. Nitrous oxide decomposition over alkali-promoted magnesium cobaltite catalysts. Chinese J. Catal. 2011, 32, 264-272. [CrossRef]

9. Iwanek, E.; Krawczyk, K.; Petryk, J.; Sobczak, J.W.; Kaszkur, Z. Direct nitrous oxide decomposition with $\mathrm{CoO}_{x}-\mathrm{CeO}_{2}$ catalysts. Appl. Catal. B Environ. 2011, 106, 416-422. [CrossRef]

10. Kim, M.-J.; Lee, S.-J.; Ryu, I.-S.; Jeon, M.-W.; Jeon, S.G. Catalytic decomposition of $\mathrm{N}_{2} \mathrm{O}$ over cobalt based spinel oxides: The role of additives. J. Molec. Catal. 2017, 442, 202-207. [CrossRef]

11. Esteves, P.; Wu, Y.; Dujardin, C.; Dongare, M.K.; Granger, P. Ceria-zirconia mixed oxides as thermal resistant catalysts for the decomposition of nitrous oxide at high temperature. Catal. Today 2011, 176, 453-457. [CrossRef]

12. Nunotani, N.; Nagai, R.; Imanaka, N. Direct catalytic decomposition of nitrous oxide gas over rhodium supported on lanthanum silicate. Catal. Commun. 2016, 87, 53-56. [CrossRef]

13. Wang, Y.; Zhang, J.; Zhu, J.; Yin, J.; Wang, H. Experimental research on catalytic decomposition of nitrous oxide on supported catalysts. Energy Convers. Manag. 2009, 50, 1304-1307. [CrossRef]

14. Pachatouridou, E.; Papista, E.; Iliopoulou, E.F.; Delimitis, A.; Goula, G.; Yentekakis, I.V.; Marnellos, G.E.; Konsolakis, M. Nitrous oxide decomposition over $\mathrm{Al}_{2} \mathrm{O}_{3}$ supported noble metals ( $\mathrm{Pt}, \mathrm{Pd}, \mathrm{Ir}$ ): Effect of metal loading and feed composition. J. Environ. Chem. Eng. 2015, 3, 815-821. [CrossRef]

15. Namuangruk, S.; Khongpracha, P.; Tantirungrotechai, Y.; Limtrakul, J. Decomposition of nitrous oxide on carbon nanotubes. J. Molec. Graph. Model. 2007, 26, 179-186. [CrossRef] [PubMed]

16. Lin, F.; Andana, T.; Wu, Y.; Szanyi, J.; Wang, Y.; Gao, F. Catalytic site requirements for $\mathrm{N}_{2} \mathrm{O}$ decomposition on Cu-, Co-, and Fe-SSZ-13 zeolites. J. Catal. 2021, 401, 70-80. [CrossRef]

17. Wang, S.; Yan, B.; Chai, J.; Li, T.; Yu, H.; Li, T.; Cao, P.; Yang, F.; Yuan, X.; Yin, H. Rhodium Encapsulated within Silicalite-1 Zeolite as Highly Efficient Catalyst for Nitrous Oxide Decomposition: From Single Atoms to Nanoclusters and Nanoparticles. Eur. J. Inorg. Chem. 2021, 23, 2201-2210. [CrossRef]

18. Liu, N.; Zhang, R.; Chen, B.; Li, Y.; Li, Y. Comparative study on the direct decomposition of nitrous oxide over M (Fe, Co, Cu)-BEA zeolites. J. Catal. 2012, 294, 99-112. [CrossRef]

19. Cürdaneli, P.E.; Özkar, S. Ruthenium(III) ion-exchanged zeolite $\mathrm{Y}$ as highly active and reusable catalyst in decomposition of nitrous oxide to sole nitrogen and oxygen. Micropor. Mesopor. Mater. 2014, 196, 51-58. [CrossRef]

20. Zhang, X.; Guan, Y.; Zhang, S.; Yang, M.; Zhao, Y.; Hao, Z. Effective catalytic decomposition of nitrous oxide over highly active and stable bimetallic CoIn-mordenite zeolite. J. Molec. Catal. Chem. 2014, 395, 202-209. [CrossRef]

21. Bols, M.L.; Snyder, B.E.R.; Rhoda, H.M.; Cnudde, P.; Fayad, G.; Schoonheydt, R.A.; Van Speybroeck, V.; Solomon, E.I.; Sels, B.F. Coordination and activation of nitrous oxide by iron zeolites. Nat. Catal. 2021, 4, 332-340. [CrossRef]

22. Nakamura, M.; Mitsuhashi, H.; Takezawa, N. Oxygen species formed on different surface sites of CaO by decomposition of $\mathrm{N}_{2} \mathrm{O}$ and the reactivity. J. Catal. 1992, 138, 686-693. [CrossRef]

23. Tan, S.A.; Grant, R.B.; Lambert, R.M. The silver-catalysed decomposition of $\mathrm{N}_{2} \mathrm{O}$ and the catalytic oxidation of ethylene by $\mathrm{N}_{2} \mathrm{O}$ over $\mathrm{Ag}(111)$ and $\mathrm{Ag} / \alpha-\mathrm{Al}_{2} \mathrm{O}_{3}$. J. Catal. 1987, 104, 156-163. [CrossRef]

24. Tabor, E.; Sádovská, G.; Bernauer, M.; Sazama, P.; Nováková, J.; Fíla, V.; Kmječ, T.; Kohout, J.; Závěta, K.; Sobalík, Z. Feasibility of application of iron zeolites for high-temperature decomposition of $\mathrm{N}_{2} \mathrm{O}$ under real conditions of the technology for nitric acid production. Appl. Catal. Environ. 2019, 240, 358-366. [CrossRef]

25. Kustov, L.M.; Khodakov, A.Y.; Kazansky, V.B. On the Nature of Active Sites for Dehydrogenation of Saturated Hydrocarbons in HZSM-5 Zeolites Modified by Zinc and Gallium Oxides. Stud. Surf. Sci. Catal. 1989, 49B, 1173-1178.

26. Kazansky, V.B.; Kustov, L.M.; Borovkov, V.Y. Near infrared diffuse reflectance study of high silica containing zeolites. Zeolites 1983, 3, 77-81. [CrossRef]

27. Bai, R.; Song, Y.; Bai, R.; Yu, J. Creation of Hierarchical Titanosilicate TS-1 Zeolites. Adv. Mater. Interfaces 2021, 8, 2001095 [CrossRef]

28. Kustov, L.M. New trends in IR-spectroscopic characterization of acid and basic sites in zeolites and oxide catalysts. Topics Catal. 1997, 4, 131-144. [CrossRef]

29. Přech, J. Catalytic performance of advanced titanosilicate selective oxidation catalysts-A review. Catal. Rev. Sci. Eng. 2018, 60, 71-131. [CrossRef]

30. Perego, G.; Bellussi, G.; Carati, A.; Millini, R. Isomorphous Substitution in Zeolite Catalysts. Stud. Surf. Sci. Catal. 1989, 44, 237-238.

31. Tatsumi, T.; Nakamura, M.; Negishi, S.; Tominaga, H. Shape-selective oxidation of alkanes with $\mathrm{H}_{2} \mathrm{O}_{2}$ catalysed by titanosilicate. J. Chem. Soc. Chem. Commun. 1990, 6, 476-477. [CrossRef]

32. Vaccaro, L.; Cannas, M.; Radzig, V. Luminescence properties of nonbridging oxygen hole centers at the silica surface. J. Non-Crystal. Solids 2009, 355, 1020-1023. [CrossRef] 